3. Mihaylenko V.V. Mathematical model of the semiconductor converter of the three-phase voltage in constant with three zoned regulations of the output voltage / V.V. Mihaylenko, V.V. Andriychuk, Y.V. Romanchuk // Dopovidi za materialamy MNTK "Suchasni prolems electroenergetyki and avtomatic". - Kyjv: Polytechnica. - 2011. - P. 417-418 (Ukr.).

УДК 621.3.011.74.005

B.B. Михайленко, канд. техн. наук, доцент, ORCID 0000-0002-0973-4612

B.A. Святненко, старший преподаватель, ORCID 0000-0002-0518-1045

Ю.М. Чуняк, ассистент, ORCID 0000-0002-4506-912X

О.С. Чарняк, студентка

Национальный технический университет Украины «Киевский политехнический институт имени Игоря Сикорского»

ИССЛЕДОВАНИЕ ЭЛЕКТРОМАГНИТНЫХ ПРОЦЕССОВ В

ПРЕОБРАЗОВАТЕЛЕ С ОДИНАДЦАТИЗОННЫМ

\title{
РЕГУЛИВАНИЕМ НАПРЯЖЕНИЯ
}

В этой статье проведено анализ электромагнитных процессов в электрических цепях с полупроводниковыми коммутаторами. Создано математическую модель для анализа электромагнитных процессов в полупроводниковых преобразователях с широтно-импульсным регулированием выходного напряжения. Приведено графики, которые отражают электромагнитные процессы в электрических цепях. При выполнении расчетов использовался метод многопараметрических функций. Математическая модель преобразователя создана для одинадцатизонного регулирования выходного напряжения. Статья посвящена развитию метода многопараметрических модулирующих функций путем разработки новых математических моделей и определения функций и алгоритмических уравнений для анализа по подсистемным составляющим электромагнитных процессов в разветвленных электрических цепях с полупроводниковыми коммутаторами и звеньями с синусоидальными, постоянными и импульсными напряжениями. Полупроводниковые коммутаторы могут осуществлять высокочастотное изменение структуры электрических цепей и широтно-импульсную модуляцию фазных и линейных напряжений трехфазной сети электропитания, реализуя регулирование выходных напряжений полупроводниковых преобразователей параметров электрической энергии.

Ключевые слова: электромагнитные процессы, выходные напряжение и ток, структура, многопараметрические модулирующие функции, полупроводниковые коммутаторы, моделирование.

Надійшла 26.05.2019

Received 26.05.2019

УДК 62-83-52.003(082)

O.O. Закладний, канд. техн. наук, доцент, ORCID 0000-0003-2813-3692 Національний технічний університет України «Київський політехнічний інститут імені Ігоря Сікорського»

\section{АЛГОРИТМИ ЗАХИСТУ ЕЛЕКТРОДВИГУНІВ ЗАСОБАМИ СУЧАСНИХ СИСТЕМ ДІАГНОСТУВАННЯ ЇХ СТАНУ}

Традиційні пристрої захисту електродвигунів в повній мірі не вирімують завдання захисту від перевантажень, ушкоджень силового живильного кабелю, перекосу фазних струмів, пов'язаних із внутрішніми аваріями двигуна або з погіршенням опору ізолящії обмоток. Рекомендації, викладені в ПУЕ стосовно захисту електродвигунів, не враховують сучасних вимог щьодо надійного захисту двигуна від перегрівання обмоток статора, зумовленого несиметрією напруги живлення, пошкодженням системи охолодження $i$ технологічними перевантаженнями, несиметрією повітряного зазору, викликаною зношуванням підшипників, заклинюванням ротора. Застосування сучасного, надійного й ефективного захисту від аварійних режимів роботи дозволяє значно скоротити кількість $і$ частоту аварійних ситуа(C) О.О. Закладний, 2019 
ціий $і$ подовжити термін служби електродвигунів, зменшити витрати електроенергії й втрати від зупинення технологічного процесу. У статті розглянуто принципи побудови захисту електродвигунів за допомогою сучасних систем діагностики енергетичного та технічного станів електропривода 3 використанням теплової моделі двигуна та контролю струму статора. В тепловій моделі враховано нагріваючі втрати, у тому числі - втрати від несиметрії і несинусоїдальності напруги. Як часострумова характеристика захисту приймається перевантажувальна характеристика електродвигуна, враховуються його початковий режим до виникнення аварійної ситуаціі та струм зворотної послідовності. В статті представлено алгоритми струмового та теплового захисту, які можуть бути застосовані при розробиі сучасних систем діагностики стану електроприводу.

Ключові слова: електропривод, система діагностування, теплова модель, струмовий захист, перевантажувальна характеристика електродвигуна, алгоритми захисту.

Вступ.

Переважна більшість існуючих пристроїв захисту асинхроних електродвигунів (АД) відрізняються один від одного за своїми функціональними можливостями і мають загальні недоліки: низьку точність встановлення струмів, спрацьовування за максимально допустимого струму, відсутність контролю напруги. Вони в повній мірі не вирішують завдання захисту АД від перевантажень, ушкоджень силового живильного кабелю, перекосу фазних струмів, пов'язаних із внутрішніми аваріями двигуна або 3 погіршенням опору ізоляції обмоток.

Метою роботи с усунення недоліків пристроїв захисту шляхом використання сучасних інтелектуальних систем діагностування їх стану.

Основні матеріали дослідження.

Аварії АД поділяються на два основних типи: механічні та електричні. До механічних належать: деформація або поломка вала ротора, ослаблення кріплення осердя статора до станини, ослаблення обпресування осердя ротора, виплавлення бабіту в підшипниках ковзання, руйнування сепаратора, кільця або кульок у підшипниках кочення, поломка крильчатки, відкладення пилу й бруду в рухомих елементах тощо [1].

Причиною більшості механічних аварій є радіальна вібрація через асиметрію мережі живлення, механічні перевантаження на валу електродвигуна, виробничий брак комплектуючих елементів або неакуратне складання. До 10\% всіх аварій АД мають механічне походження. 3 них $8 \%$ складає частка аварій, пов'язаних з асиметрією фаз, і лише 2\% - аварії, пов'язані з механічним перевантаженням. Частка аварій, пов'язаних з браком є незначною ,тому їі можна не брати до уваги. На сьогодні оцінка ймовірностей виникнення механічних аварій відсутня. Більша їх частина має прихований характер і виявляється лише після відповідних випробувань або розбирання двигуна, однак постійний контроль мережевої напруги та струму АД дозволяє у більшості випадків звести цю ймовірність до мінімуму.

Електричні аварії АД, у свою чергу, поділяються на три типи:

- мережеві аварії;

- струмові аварії, пов'язані з обривом провідників у обмотках статора, ротора або кабеля, міжвитковим і міжфазним замиканнями обмоток, порушенням контактів і руйнуванням з'єднань, виконаних за допомогою паяння або зварювання; аварії, пов'язані $з$ пробоєм ізоляції в результаті нагрівання, викликаного протіканням струмів перевантаження або короткого замикання (к.з.);

- аварії, пов'язані зі зниженням опору ізоляції внаслідок її старіння, руйнування або зволоження.

Для того, щоб захистити АД від аварійних режимів, застосовують релейний захист: тепловий, струмовий, температурний і комбінований. Багаторічний досвід експлуатації АД показав, що більшість існуючих пристроїв захисту не гарантують їх безаварійної роботи [1]. Застосування надійного й ефективного захисту від аварійних режимів роботи дозволяє значно скоротити кількість і частоту аварійних ситуацій і подовжити термін служби АД, зменшити витрати електроенергії й втрати від зупинення технологічного процесу.

Рекомендації, викладені в ПУЕ стосовно захисту АД, не враховують сучасних вимог щодо надійного захисту двигуна від перегрівання обмоток статора, зумовленого несиметрією напруги живлення, пошкодженням системи охолодження і технологічними перевантаженнями, несиметрією повітряного зазору, викликаною зношуванням підшипників, заклинюванням ротора [2].

Одним із перспективних видів захисту від перевантаження є застосування сучасних систем діагностування із використанням математичного моделювання теплового стану АД. У практичних розрахунках найчастіше застосовується розрахунок нагрівання за експонентою, тобто представлення АД одним тілом нагрівання та диференціальним рівнянням першого порядку (рівняння теплового стану)

$$
\frac{d \Delta \tau}{d t}=\frac{1}{C}[\Delta P-A \Delta \tau]
$$


де $\Delta \tau$ - перевищення температури двигуна над температурою довкілля; $t$ - час; $\Delta P$ - потужність втрат енергії в двигуні; $C$ - сумарна теплоємність двигуна; $A$ - сумарна тепловіддача [3].

У різницевій формі, придатній для реалізації на цифровому пристрої, це рівняння має вигляд

$$
\Delta \tau_{k}=\Delta \tau_{k-1}+\frac{\Delta h}{T_{\mathrm{H}}}\left(\frac{\left(V_{1}+V_{2}+\Delta P_{\text {дн }}+\Delta P_{\text {дт }}\right) \Delta \tau_{\text {із }}}{1,3 \Delta P_{\text {н }}}-\Delta \tau_{k-1}\right),
$$

де $\Delta \tau_{k}$ - перевищення температури в $k$-й момент часу; $\Delta \tau_{k-1}$ - перевищення температури в $(k-1)$ ий - момент часу; $\Delta h$ - крок розрахунку, $V_{1}, V_{2}$ - втрати в обмотках статора і ротора, $\Delta P_{\text {дн }}, \Delta P_{\text {дт }}-$ додані і додаткові втрати в АД, $\Delta P_{\text {н }}$ - номінальні втрати в АД, $T_{\text {н }}$ стала часу нагрівання при номінальному навантаженні, $\Delta \tau_{\text {iз }}$ - гранично припустиме перевищення температури ізоляції відповідного класу.

Алгоритм роботи теплового захисту наведено на рис.1. Повне врахування всіх факторів для забезпечення надійного теплового захисту АД практично неможливе, тому доцільно тепловий захист поєднувати зі струмовим .

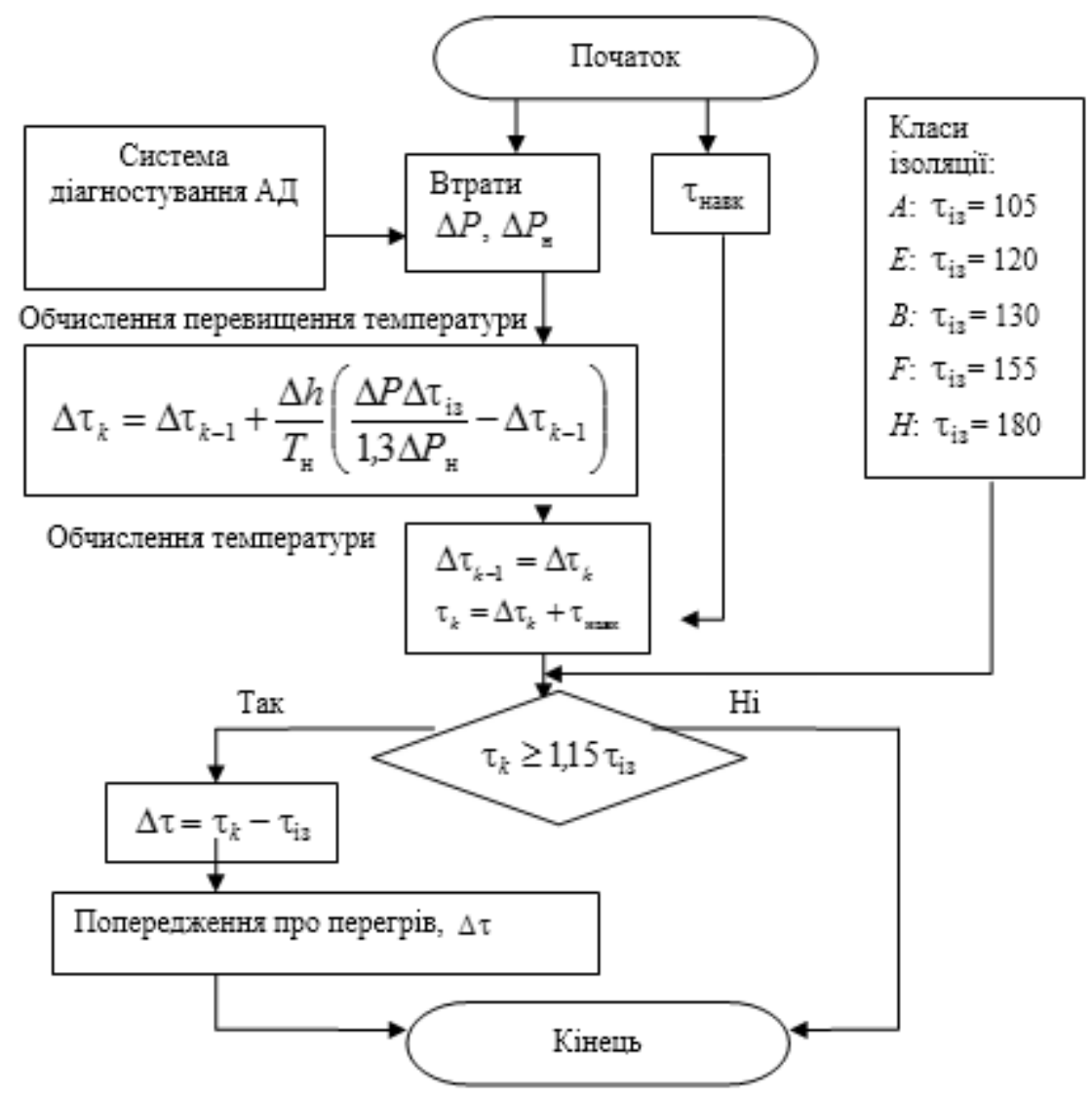

Рисунок 1 - Алгоритм роботи теплового захисту

Аварійні режими роботи в більшості випадків супроводжуються проходженням надструмів у обмотці статора. Небезпечними є насамперед тепловий вплив надструмів і тривалість його проходження. Чим більша кратність струму перевантаження $k_{I}$ відносно номінального струму, тим менший припустимий час перевантаження

$$
t=T_{\text {н }} \ln \frac{1}{1-\frac{\Delta \tau_{\text {із }}-\Delta \tau_{0}}{k_{I}^{2} \Delta \tau_{\text {ном }}}},
$$


де $\Delta \tau_{0}$ - початкове перевищення температури двигуна [4].

Спрощено формула (1) має вигляд

$$
t=T_{\text {н }} \ln \frac{k_{I}^{2}-k_{\text {поч }}^{2}}{k_{I}^{2}-a},
$$

де $k_{\text {поч}}$ - початковий коефіцієнт кратності струму, $a=\frac{\Delta \tau_{\text {iз }}}{\Delta \tau_{\text {ном }}}-$ коефіцієнт, який змінюється в межах 1-1,5 і в середньому приймається таким, що дорівнює 1,3 [5].

На рис. 2 зображена перевантажувальна характеристика АД з різними початковими режимами.

В [6] наводиться кілька варіантів часострумової характеристики захисту:

$$
\begin{gathered}
t=A_{1} \ln \frac{k_{I}^{2}}{k_{I}^{2}-1}, \\
t=\frac{A_{2}}{k_{I}^{2}}, \\
t=\frac{A_{3}}{k_{I}^{2}-1},
\end{gathered}
$$

де $A_{1}, A_{2}, A_{3}$ - сталі величини, які вибираються меншими $T_{\text {н }}$ із запасом, який залежить від можливої похибки дії захисту.

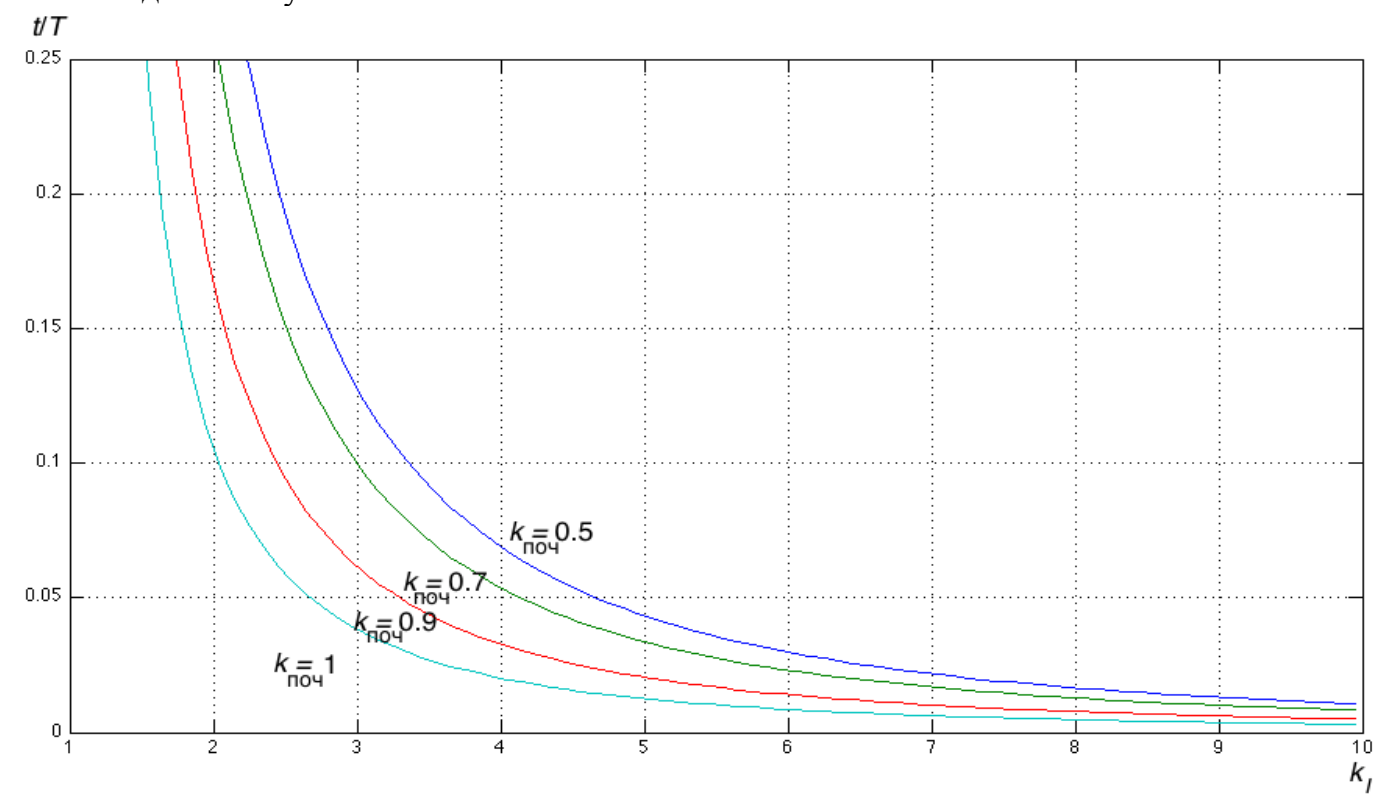

Рисунок 2 - Перевантажувальна характеристика АД

Часострумова характеристика захисту з урахуванням температури навколишнього повітря визначається виразом

$$
t=A_{1} \ln \frac{k_{I}^{2}}{\left(1-\frac{\tau_{\text {навк }}}{\tau_{\text {дв.доп }}}\right)\left(k_{I}^{2}-1\right)},
$$


де $\tau_{\text {дв.доп }}$ - відповідає температурі АД при струмі перевантаження $(1,15-1,5) I_{\text {ном }}$, коли перегрівання призводить до скорочення терміну служби ізоляції.

Взявши як вихідну точку за ГОСТ $183-74 *\left(t=120 \mathrm{c}, k_{I}=1,5\right)$, з урахуванням коефіцієнта запасу $k_{3}=1,1$ можна знайти значення $A$ для формул (2) - (4):

$$
\begin{gathered}
t=186 \ln \frac{k_{I}^{2}}{k_{I}^{2}-1}, \\
t=\frac{245}{k_{I}^{2}}, \\
t=\frac{136}{k_{I}^{2}-1} .
\end{gathered}
$$

Для рівняння (5) приймаємо $\tau_{\text {навк }}=25^{\circ} \mathrm{C}$, а $\tau_{\text {дв.доп }}=165^{\circ} \mathrm{C}$ для класу ізоляції $B$. Тоді

$$
t=145 \ln \frac{k_{I}^{2}}{0,85\left(k_{I}^{2}-1\right)} .
$$

Як видно з рис.3, часострумові характеристики захисту за формулами (2), (3), (4) значною мірою відрізняються в початковій частині, при незначних струмах перевантаження, а характеристика (5) значно відрізняється від інших при значеннях $k_{I}>1,5$.

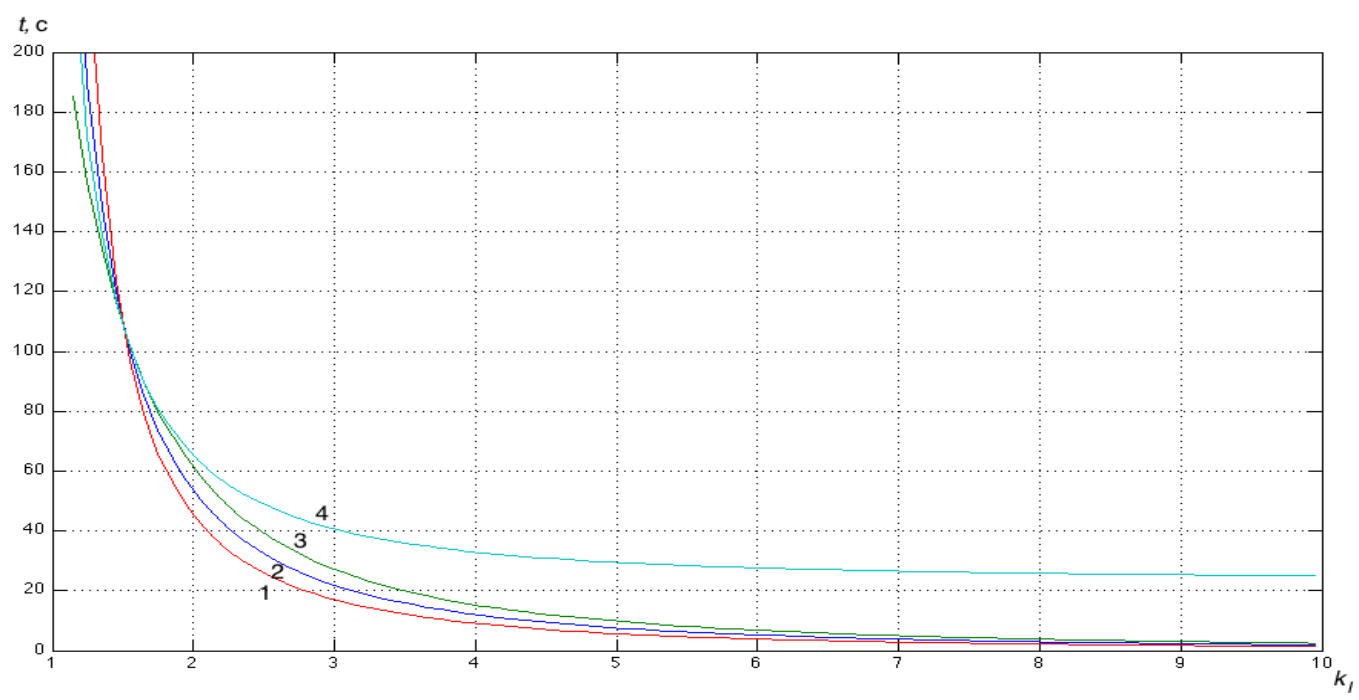

Рисунок 3 - Часострумова характеристика спрацювання захисту: 1 - ф. (8), 2 - ф. (6), 3 - ф. (7), 4 - ф. (9)

Вирази (6) - (9) можуть використовуватися лише для загальної оцінки процессу нагрівання, оскільки базуються лише на одній точці ГОСТ 183-74*. Для точнішого вибору захисного пристрою, наприклад з часострумовою характеристикою типу (3), можна скористатися виразом [4]

$$
A_{2}=\alpha_{\text {зап }} k_{\Pi}^{2} t_{\text {п }}
$$

де $\alpha_{\text {зап }}$ - коефіцієнт, що гарантує відсутність помилкових спрацьовувань захисту при пуску, $k_{\text {п }}$ кратність пускового струму, $t_{\text {п }}$ - тривалість пуску двигуна. 
Для часострумової характеристики (4) згідно [7] приймають $A_{3}=250$ (для закритих АД, що мають великі вагу і розміри) і $A_{3}=150$ (для відкритих АД).

У існуючих пристроїв перевантажувальна здатність двигуна (рис.4) повною мірою не використовується, що є значним недоліком захисту. Особливо це стосується невеликого перевантаження. Таким чином, як часострумову характеристику захисту пропонується використовувати перевантажувальну характеристику. Це дозволяє налагоджувати захист під параметри конкретного АД.

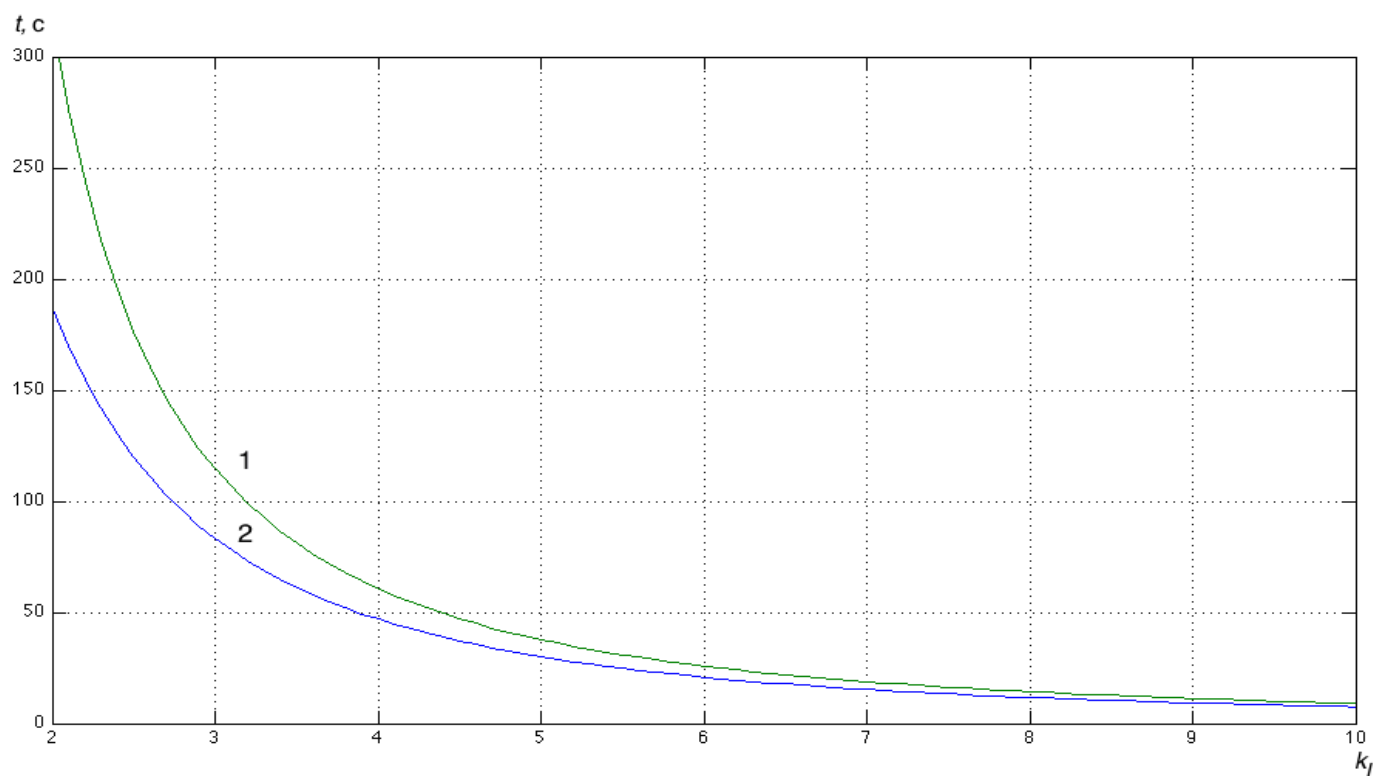

Рисунок 4 - 1 - перевантажувальна характеристика двигуна АД 4A280S2У3, 2 - часострумова характеристика захисту

На рис.5 наведено алгоритм роботи струмового захисту.

АД можуть отримувати теплове перевантаження струмами зворотної послідовності при фазних струмах нижчих струмів спрацювання теплових реле існуючих систем захисту. Наприклад, при «злипанні фаз» або обриві фази зі сторони високої напруги у понижувального трансформатора зі схемою з’єднання «трикутник-зірка» із заземленою нейтраллю струм в одній із фаз в 2 рази перевищує струм у двох інших [4]. Абсолютні значення струмів прямої та зворотної послідовності дорівнюють один одному, тобто $\left|I_{1}\right|=\left|I_{2}\right|$. Таким чином, захист АД за струмом повинен ураховувати струм зворотної послідовності.

Еквівалентний фазний струм з урахуванням струму зворотної послідовності

$$
I_{\mathrm{e \kappa в}}=\sqrt{I_{\max }^{2}+k I_{2}^{2}}
$$

де $I_{\max }$ - діюче значення найбільшого фазного струму, $I_{2}$ - діюче значення складової зворотної послідовності, $k$ - ваговий коефіцієнт струму $I_{2}$ [8].

Для АД $k$ можна знайти за формулою

$$
k=2 \frac{M_{\Pi}}{M_{\mathrm{H}}} \frac{1}{s_{\mathrm{H}} k_{\Pi}^{2}}-1,
$$

де $M_{\text {п }}, M_{\text {н }}$ - пусковий та номінальний обертові моменти АД, $k_{\text {п }}$ - кратність пускового струму, $s_{\text {н }}$ - номінальне ковзання. Зазвичай для АД типовим значенням $є k_{п}=4,5$ [9]. 


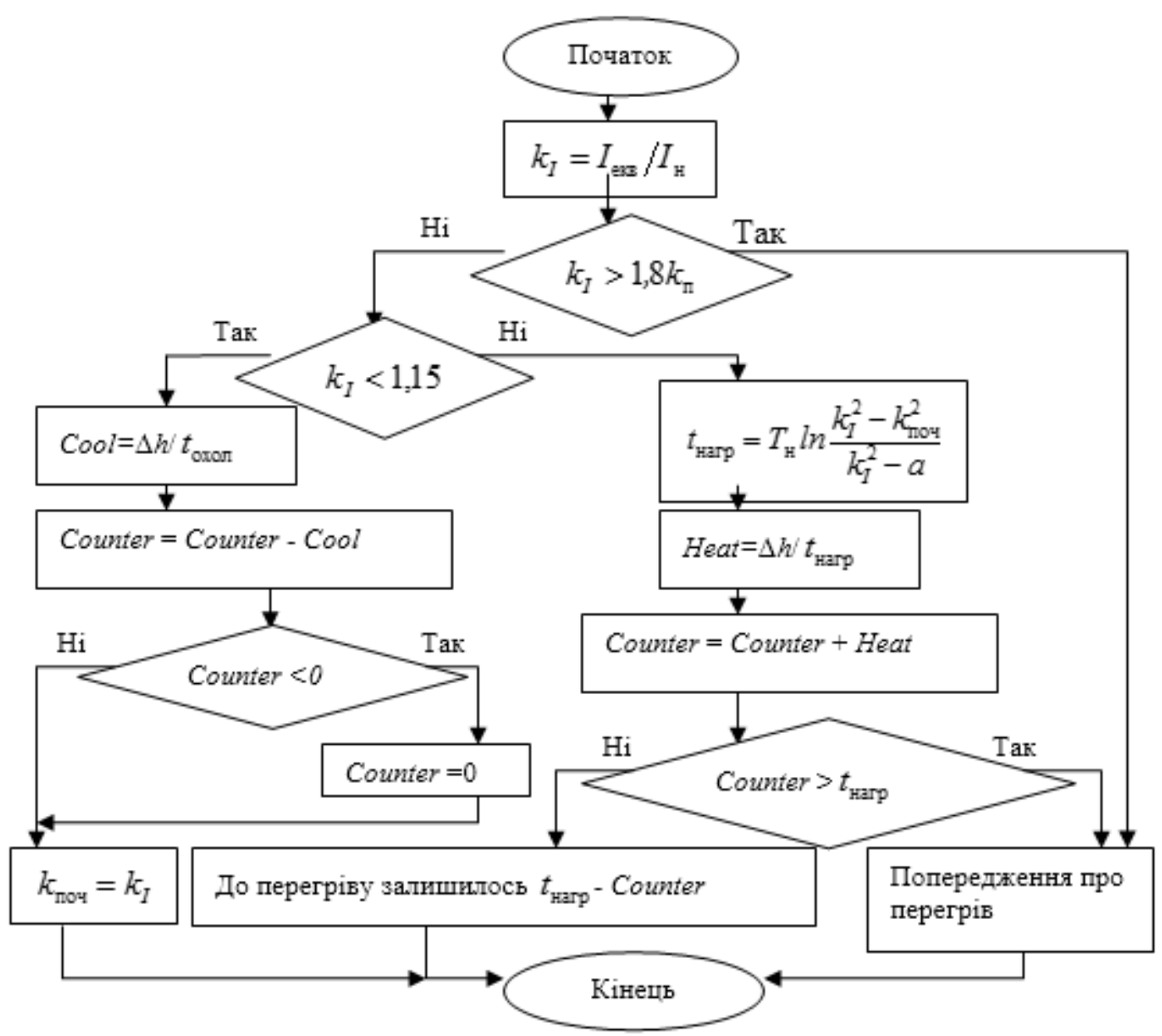

Рисунок 5 - Алгоритм роботи струмового захисту АД

Згідно ГОСТ 13109-97 дозволяється розраховувати напруги зворотної послідовності за спрощеною формулою $U_{2 i}=0,62\left(U_{i \max }-U_{i \min }\right)$, де $U_{i \max }, U_{i \min }$ - найбільше та найменше діюче значення 3 трьох міжфазних напруг при $i$-ому спостереженні з урахуванням гармонічних складових цих напруг при коефіцієнті спотворень синусоїдальності кривих напруги, який не перевищує $5 \%$. Похибка розрахунків не перевищує $8 \%$.

Використовуючи співвідношення складових зворотної послідовності для струмів і напруг при переході від схеми з'єднання «трикутник» до схеми «зірка», можна перетворити наближену формулу для напруги зворотної послідовності у формулу струму зворотної послідовності у фазах трипровідної мережі

$$
I_{2 i}=1,074\left(I_{i \max }-I_{i \min }\right)
$$

де $I_{i \max }, I_{i \min }$ - найбільше та найменше з трьох діючих значень фазних струмів в лінії $i$-ому спостереженні з урахуванням гармонічних складових цих струмів при коефіцієнті спотворень синусоїдальності кривих струму не більше $5 \%$.

Таким чином, підставляючи (11) в (10), з урахуванням струму зворотної послідовності спрощено можна записати

$$
k_{I}=\frac{\sqrt{6,19 I_{\max }^{2}-5,19 I_{\min }^{2}}}{I_{\mathrm{H}}} .
$$

Додатково рекомендується обмежувати струм зворотної послідовності значенням $(0,2 \ldots 0,25) I_{\text {н }}$ [8]. 
Мінімальний захист встановлюється на АД, які необхідно вимикати при пониженій напрузі для запобігання самозапуску відповідальних двигунів, а також АД, самозапуск яких при відновленні напруги неприпустимий за умовами безпеки або особливостей технологічного процесу [10].

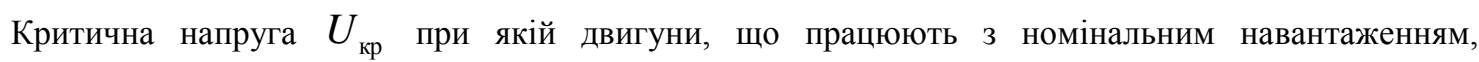
перекидаються

$$
U_{\text {кр }} \leq U_{\text {ном }} \sqrt{\frac{M_{\text {ном }}}{M_{\text {max }}}},
$$

де $M_{\text {ном }}, M_{\max }$ - номінальний і максимальний моменти АД.

Напруга спрацьовування захисту приймається такою, що дорівнює $U_{\text {кр}}$, витримка часу на відімкнення 0,5 ..1,5 с - для відповідальних двигунів, для інших АД - 10..15 с.

Висновок. Вдосконалено моделі та алгоритми захисту АД на основі його теплової моделі та контролю струмів обмотки статора, у яких враховано: всі нагріваючі втрати, у тому числі - втрати від несиметрії і несинусоїдальності напруги; струм зворотної послідовності через коефіцієнт кратності струму перевантаження; перевантажувальну характеристику діагностованого двигуна як часострумову характеристику захисту.

\section{Список літератури}

1. Соркинд М. Асинхронные электродвигатели 0,4 кВ. Аварийные режимы работы / М. Соркинд // «Новости Электротехники», №2(32), 2005.

2. Сивокобыленко В.Ф. Тепловая защита асинхронного двигателя с короткозамкнутым ротором при несимметрии питающего напряжения / В.Ф. Сивокобыленко, С.Н. Ткаченко // Вісник КДПУ ім. М. Остроградського. - 2009 . - Вип. 3(56)., ч.2. - С. 74-78.

3. Синчук О.Н. Тепловая модель кранового АД для диагностирования и настройки цифровой защиты от перегрузок / О.Н. Синчук, В.В. Чумак, С.Л. Михайлов // Электротехника, 2003. - №3. - С. 6166.

4. Гимоян Г.Г. Релейная защита горных электроустановок / Г.Г. Гимоян. - изд. 2, перераб. и доп. М.: «Недра», 1978, 349 с.

5. Сыромятников И.А. Режимы работы асинхронных и синхронных двигателей / И.А. Сыромятников Под ред. Л.Г. Мамикоянца. - 4-е изд., переработ. и доп. - М.: Энергоатомиздат, 1984 . - 240 с., ил.

6. Корогодский В.И. Релейная защита электродвигателей напряжением выше 1 кВ / В.И. Корогодский, С.Л. Кужеков, Л.Б. Паперно - М.: Энергоатомиздат, 1987 - 248 с.

7. Коваленский И.В. Релейная защита электродвигателей высокого напряжения / И.В. Коваленский, - Л.: Энергия, 1964 - 81 с.

8. Сушко В. Защита низковольтных электродвигателей совершенных устройств / В. Сушко // «Новости Электротехники», №5(35), 2005.

9. Schneider Electric. Серия Sepam. Sepam1000+. Подстанция. Трансформатор. Двигатель. Сборные шины. Защита и контроль. - 2001.

10. Чернобровов Н.В. Релейная защита энергетических систем: Учеб. пособие для техникумов / Н.В. Чернобровов, Семенов В.А. - М.: Энергоатомиздат, 1998. - 800 с.: ил.

O. Zakladnyi, Cand. Sc. (Eng.), Assoc. Prof., ORCID 0000-0003-2813-3692 National Technical University of Ukraine "Igor Sikorsky Kyiv Polytechnic Institute"

\section{ALGORITHMS OF PROTECTION OF ELECTRIC MOTORS BY MEANS OF MODERN SYSTEMS OF DIAGNOSTIC OF THEIR STATES}

Traditional motor protection devices do not completely solve the problem of overload protection, damage to the power supply cable, distortion of phase currents associated with internal motor crashes, or deterioration of the insulation resistance of windings. requirements for reliable protection of the motor against overheating of the stator windings, caused by power supply asymmetry, damage to the cooling system and technological overloads, asymmetry air gap caused by wear of bearings, rotor jamming. The use of modern, reliable and effective protection against accidental operation modes can significantly reduce the number and frequency of accidents and lengthen 
the lifespan of electric motors, reducing power consumption and losses from the suspension process. The principles of protection of electric motors with the help of modern systems of diagnostics of power and technical states of the electric drive using thermal model of the engine and control of stator current are considered in the article. The thermal model takes into account heating losses, including losses from asymmetry and non-sinusoidal voltage. The overload characteristic of an electric motor is taken as a temporary characteristic of protection, its initial mode before the occurrence of an emergency and the current of the reverse sequence are taken into account. The article presents the algorithms of current and thermal protection that can be applied in the development of modern systems of diagnostics of the condition of the drive.

Keywords: electric drive, diagnosis system, thermal model, current protection, motor overload characteristic, protection algorithms.

\section{References}

1. Sorkind M. Asynchronous motors $0.4 \mathrm{kV}$. Emergency operating modes / M. Sorkind // "Electrical Engineering News", №2 (32), 2005.

2. Sivokobylenko V.F. Thermal protection of an asynchronous motor with a short-circuited rotor with asymmetry of the supply voltage / V.F. Sivokobylenko, SN Tkachenko // Bulletin of the KSPU them. M. Ostrogradsky. - 2009. - No. 3 (56), part 2. - P. 74-78.

3. Sinchuk ON Thermal model of crane AD for the diagnosis and adjustment of digital overload protection / ON. Sinchuk, V.V. Chumak, S.L. Mikhailov // Electrical Engineering, 2003. - №3. - pp. 61-66.

4. Gimoyan GG Relay protection of mountain electrical installations / G.G. Himoyan. - ed. 2, rework. and ext. M .: Nedra, 1978, 349 p.

5. Syromyatnikov IA Modes of operation of asynchronous and synchronous motors / IA Syromyatnikov Ed. L.G. Mamikoyanets. - 4th ed., Reworking. and ext. - M .: Energoatomizdat, 1984. - 240 pp., Ill.

6. Korogodsky VI Relay protection of motors above 1 kV / VI Korogodsky, S.L. Kuzhekov, L.B. Paper M .: Energoatomizdat, 1987 - 248 p.

7. Kovalensky IV Relay protection of high voltage electric motors / IV. Kovalensky, L .: Energy, $1964-81$ p.

8. Sushko V. Protection of low-voltage electric motors of perfect devices / V. Sushko // «Electrical Engineering News», №5 (35), 2005.

9. Schneider Electric. Sepam series. Sepam1000 +. Substation. Transformer. Engine. Precast tires. Protection and control. - 2001.

10. Chernobrov NV Relay protection of power systems: Textbook. manual for technical schools / NV Chernobrov, VA Semenov - M .: Energoatomizdat, 1998. - 800 p.: Ill.

\section{УДК 62-83-52.003(082)}

O.А. Закладной, канд. техн. наук, доцент, ORCID 0000-0003-2813-3692 Национальный технический университет Украины «Киевский политехнический институт имени Игоря Сикорского»

\section{АЛГОРИТМЫ ЗАЩИТЫ ЭЛЕКТРОДВИГАТЕЛЕЙ СРЕДСТВАМИ СОВРЕМЕННЫХ СИСТЕМ ДИАГНОСТИКИ ИХ СОСТОЯНИЯ}

Традиционные устройства защиты электродвигателей в полной мере не решают задач защить от перегрузок, повреждений силового питающего кабеля, перекоса фазных токов, связанных с внутренними авариями двигателя или с ухудшением сопротивления изоляции обмоток. Рекомендации, изложенные в ПУЭ по защите электродвигателей, не учитывают современных требований по надежной защчиты двигателя от перегрева обмоток статора, обусловленного несимметрией напряжения питания, повреждением системы охлаждения и технологическими перегрузками, несимметрию воздушного зазора, вызванной износом подшипников, заклинивание ротора. Применение современного, надежного и эффективного защиты от аварийных режимов работы позволяет значительно сократить количество и частоту аварийных ситуаций и продлить срок службы электродвигателей, уменьшить расходьь электроэнергии и потери от остановки технологического процесса. В статье рассмотрены принципы построения защиты электродвигателей с помощью современных систем диагностики энергетического и технического состояний электропривода с использованием тепловой модели двигателя и контроля тока статора. В тепловой модели учтено нагревательные потери, в том числе - потери от несимметрии и несинусоидальности напряжения. Как часострумова характеристика защиты принимается перегрузочная характеристика электродвигателя, учитываются его начальный режим к возникновению аварийной ситуации и ток обратной последовательности. В статье представлень алгоритмы токовой 
тепловой защиты, которые могут быть применены при разработке современных систем диагностики состояния электропривода.

Ключевые слова: электропривод, система диагностирования, тепловая модель, токовая защита, перегрузочная характеристика электродвигателя, алгоритмы защиты.

В. М. Кутін д-р техн. наук, професор

С. А. Бондаренко д-р техн. наук, доцент

М. В. Кутіна канд. техн. наук, доцент

Вінницький національний технічний університет

\section{МЕТОД РИЗИК-АНАЛІЗУ ДЛЯ ПРОГНОЗУВАННЯ ТЕХНІЧНОГО СТАНУ ЕЛЕКТРООБЛАДНАННЯ ТРАНСФОРМАТОРНИХ ПІДСТАНЦІЙ}

В статті запропоновано метод ризик-аналізу для прогнозування технічного стану електрообладнання трансформаторних підстаниій. Розглянуто функціональну стратегію ризик менеджменту для подальшого вдосконалення експлуатащії електрообладнання шляхом підвищення якості і ефективності системи технічного обслуговування і ремонту на основі виявлення областей ризику та їх оцінювання, запобігання виникнення небажаних наслідків шляхом прогнозування та оцінювання технічного стану електрообладнання для прийняття рішень.

Ключові слова: силове електрообладнання, технічна експлуатація, менеджмент, діагностика, ризиканаліз

Вступ. Існуюча система технічного обслуговування і ремонту (СТОР) трансформаторних підстанцій складається 3 моніторингу технічного стану (ТС) електрообладнання, аналізу отриманих результатів ТС, проведення ремонтів - відновлення ресурсу електрообладнання, оцінювання матеріальних і фінансових витрат $[1,2,3]$.

Найбільш поширеною формою проведення технічного обслуговування і ремонту (ТО і P) $\epsilon$ комплексний метод виконання робіт [2]. Цей метод базується на принципі сумісництва виконання робіт за місцем і часом, що дозволяє зменшити витрати часу на підготовчі заключні операції, переходи, переїзди, ефективніше використовувати засоби механізації, підвищити рівень керівництва роботами, їх виконання.

Для керування технічним станом роботи групуються в комплекси, які відрізняються за періодичністю і номенклатурою. У загальному випадку [4] елемент трансформаторної підстанції (ТП) відмовить і буде відновлений до моменту попереджувального відновлення з ймовірністю

$$
Q\left(T_{p}\right)=\int_{T_{\min }}^{T_{p}} f(T) d T
$$

де $f(T)$ - щільність розподілу напрацювання на відмову; $T_{\min }-$ мінімальний час напрацювання на відмову.

Середнє напрацювання на відмову за умови, що воно виникло до $T$ визначають як

$$
T^{\prime}=\int_{T_{\min }}^{T_{p}} T \cdot f(T) d T / Q\left(T_{p}\right) .
$$

(C) В. М. Кутін, Є. А. Бондаренко, М. В. Кутіна, 2019 